\title{
PRESTASI AKADEMIK DITINJAU DARI KETERLIBATAN REMAJA DALAM KEGIATAN EKSTRAKURIKULER
}

\author{
Kamilia Nur Umamah', Melati Putri², Nabilah Edyta ${ }^{3}$, Andi Tenri Faradiba ${ }^{4}$ \\ ${ }^{1}$ Fakultas Psikologi, Universitas Pancasila \\ Email: kamilian.umamah@gmail.com \\ ${ }^{2}$ Fakultas Psikologi, Universitas Pancasila \\ Email: melatiputriar@ymail.com \\ ${ }^{3}$ Fakultas Psikologi, Universitas Pancasila \\ Email: edytanabilah@gmail.com \\ ${ }^{4}$ Fakultas Psikologi, Universitas Pancasila \\ Email: atenrifaradiba@univpancasila.ac.id
}

\begin{abstract}
ABSTRAK
Kegiatan ekstrakurikuler merupakan kegiatan yang dilakukan di luar jam pelajaran untuk memperluas wawasan pengetahuan yang telah dimiliki dari berbagai bidang studi. Penelitian ini bertujuan untuk melihat hubungan antara kegiatan ekstrakurikuler dengan prestasi akademik pada mahasiswa. Jumlah subjek pada penelitian ini adalah 640 orang. Subjek diambil dengan menggunakan teknik acidental sampling, yaitu jenis sampling nonprobabiliti yang melibatkan sampel diambil dari bagian populasi yang dekat dengan sumber data. Alat ukur dalam penelitian ini yaitu dengan menggunakan kuesioner 11 item skala likert 5 poin untuk mengukur keterlibatan dalam kegiatan ekstrakurikuler dan prestasi akademik menggunakan nilai IPK. Hasil penelitian ini menunjukan bahwa ada hubungan antara kegiatan kegiatan ekstrakurikuler dengan prestasi akademik mahasiswa dengan sig $p>0.001$.
\end{abstract}

Kata kunci: ekstrakurikuler, prestasi, akademik, keterlibatan, remaja

\section{PENDAhuluan}

Mahasiswa sebagai Agent of Change memiliki peran penting dalam suatu perubahan, dimana perubahan tersebut diharapkan dapat memberikan dampak yang signifikan dan mampu memberikan sumbangsih terbaik untuk kemajuan bangsa. Dengan menyadari tanggung jawabnya tersebut, mahasiswa diharapkan mampu mengembangkan kemampuan dan keterampilannya bukan hanya dari aktivitas perkuliahan dan fokus terhadap akademiknya saja, akan tetapi dari berbagai jenis kegiatan di lingkungan kampus. Salah satunya menjadi anggota dalam bidang organisasi atau ekstrakurikuler, baik organisasi kemahasiswaan, maupun organisasi diluar kemahasiswaan, merupakan salah satu dari sekian banyak cara untuk mencari pengalaman baru serta mendapatkan ilmu-ilmu baru yang bermanfaat.

Fenomena ini merupakan suatu hal yang menarik untuk dikaji lebih lanjut, karena sampai saat ini kegiatan ekstrakurikuler merupakan salah satu kegiatan yang masih menuai pro dan kontra baik dikalangan pelajar, mahasiswa, dan masyarakat. Dimana apakah ketika individu terlibat dalam kegiatan ekstrakurikuler akan memberikan dampak yang positif untuk pencapaian akademiknya atau justru menjadi faktor yang menghambat pencapaian akademiknya. Sehingga peneliti tertarik untuk mengkonfirmasi hipotesa mengenai apakah terdapat hubungan anatara kegiatan ekstrakurikuler dan prestasi akademik pada mahasiwa. Berdasarkan penelitian sebelumnya (Darling dan kawan-kawan 2005, dalam Knifsend dan Graham 2012) menemukan bahwa kegiatan organisasi berhubungan dengan prestasi akademik pada siswa sekolah menengah yang aktif dalam satu atau lebih banyak kegiatan serta memberikan dampak positif disekolah seperti keinginan yang kuat untuk mencapai keberhasilan pencapaian akademik, dibandingkan dengan siswa yang kurang aktif dalam kegiatan ekstrakurikuler. 
Kemudian dalam penelitian (Dworkin dan kawan-kawan 2003, dalam Knifsend dan Graham 2012) menemukan bahwa kegiatan organisasi memiliki hubungan dengan prestasi akademik, dimana mereka yang aktif dalam kegiatan ekstrakurikuler memiliki lebih banyak hal yang dapat dilakukan untuk membangun hubungan yang kuat dan suportif serta mendapatkan manfaat lainnya berupa pengalaman belajar dari kegiatan yang berbeda. Sejalan dengan dua penelitian lainnya, (Eccles 2006, dalam Knifsend dan Graham 2012) menemukan bahwa kegiatan organisasi berhubungan dengan prestasi akademik, yaitu ketika siswa terlibat dalam beberapa kegiatan ekstrakurikuler menunjukan hasil bahwa mereka memperoleh nilai rata-rata yang lebih tinggi dan memiliki harapan yang lebih besar tentang pencapaian akademik dimasa sekolah dan setelah sekolah menengah.

Mahasiswa yang berminat dalam organisasi atau ekstrakurikuler dapat menyalurkan bakat, minat, dan kemampuan mereka (Lerner, 2005, dalam Mahoney, J. L., Larson, R. W., \& Eccles, J. S.). Berbagai perguruan tinggi menyediakan sarana untuk membantu mahasiswa mengembangkan potensinya dalam mengembangkan diri. Program yang disediakan merupakan sarana untuk mendukung peningkatan kualitas dan kreativitas mahasiswa di bidang penalaran dan keilmuan, bakat, minat dan kemampuan, kesejahteraan, kepedulian sosial dan kegiatan penunjang. Peningkatan kualitas yang dimaksud disini adalah dengan mengembangkan hard skill yang dimiliki oleh setiap mahasiswa. Hard skill berkaitan dengan penguasaan materi perkuliahan (teori), sedangkan soft skill lebih kearah penguat hard skill. Menurut Wagner (2008, dalam Fakhriyah, 2014), yang termasuk soft skill salah satunya berupa kemampuan berpikir kritis dan pemecahan masalah. Dalam hal ini, sarana yang mendukung mampu meningkatkan prestasi akademik mahasiswa.

\section{Prestasi Akademik}

Prestasi akademik merupakan perubahan dalam hal kecakapan tingkah laku, ataupun kemampuan yang dapat bertambah selama beberapa waktu dan tidak disebabkan proses pertumbuhan, tetapi adanya situasi belajar. Perwujudan bentuk hasil proses belajar tersebut dapat berupa pemecahan lisan maupun tulisan, dan keterampilan serta pemecahan masalah langsung dapat diukur atau dinilai dengan menggunakan tes yang berstandar (Sobur, 2006). Prestasi akademik adalah istilah untuk menunjukkan suatu pencapaian tingkat keberhasilan tentang suatu tujuan karena suatu usaha belajar telah dilakukan oleh seseorang secara optimal (Setiawan, 2006, Chairiyanti, 2013). Menurut Winkel (1987, dalam Kurniawat, R., \& Leonardi, T., 2013), prestasi akademik ialah penampakan hasil belajar seseorang yang merupakan hasil suatu penilaian dibidang pengetahuan, keterampilan dan sikap sebagai hasil belajar seseorang yang dinyatakan dalam bentuk nilai. Prestasi akademik biasanya diukur dengan ujian yang menilai pengetahuan tentang keterampilan dan pengetahuan yang telah dipelajari oleh mahasiswa (Engel, 2002; Bennet, 2003; Bishin, 1973; dalam Joe, A, I \& Okoto, T., 2014). Sedangkan menurut Rivkin, S. G., Hanushek, E. A., \& Kain, J. F. (2005), prestasi akademik adalah fungsi kumulatif dari pengalaman keluarga, komunitas, dan sekolah sebelumnya.

\section{Kegiatan Organisasi}

Kegiatan adalah suatu peristiwa atau kejadian yang pada umumnya tidak dilakukan secara terus menerus, sedangkan organisasi adalah sekelompok orang (dua atau lebih) yang secara formal dipersatukan dalam suatu kerjasama untuk mencapai tujuan yang telah ditetapkan. Kerjasama tersebut dapat dibangun dengan mengikuti kegiatan-kegiatan yang dapat meningkatkan prestasi akademik. Menurut Uzer dan Lilis (1993: 22, dalam Inriyani, Y., Wahjoedi, W., \& Sudarmiatin, S., 2016), ekstrakurikuler merupakan kegiatan yang dilakukan di luar jam pelajaran (tatap muka) baik dilaksanakan di sekolah maupun di luar sekolah dengan maksud untuk lebih memperkaya dan memperluas wawasan pengetahuan dan kemampuan yang telah dimilikinya 
dari berbagai bidang studi. Adapun kegiatan mahasiswa di perguruan tinggi yaitu kegiatan ekstrakurikuler berupa organisasi mahasiswa.

Kegiatan organisasi adalah suatu peristiwa atau kejadian yang dilakukan oleh sekelompok orang yang dipersatukan secara formal, di luar jam pelajaran, baik di dalam lingkungan sekolah maupun di luar lingkungan sekolah untuk memperluas pengetahuan dan kemampuan yang dimiliki. Sedangkan definisi kegiatan ektrakurikuler menurut Depdikbud (1984:6), adalah kegiatan yang dilakukan di luar jam pelajaran tatap muka, dilaksanakan di sekolah atau di luar sekolah agar lebih memperkaya dan memperluas wawasan pengetahuan dan kemampuan yang telah dipelajari dari berbagai mata pelajaran dalam kurikulum. Kegiatan organisasi bertujuan melatih mahasiswa untuk belajar hidup bermasyarakat, belajar untuk memecahkan berbagai permasalahan, dan mendapatkan ilmu yang tidak di dapat dalam perkuliahan (Lerner, 2005, dalam Mahoney, J. L., Larson, R. W., \& Eccles, J. S.).

Menurut Lerner (2005, dalam Mahoney, J. L., Larson, R. W., \& Eccles, J. S.), ada empat W yang dapat mendeskripsikan kegiatan organisasi untuk orang muda, yaitu who, where, what, dan when. Orang yang mengikuti kegiatan organisasi adalah anak sekolah atau mahasiswa, anak-anak, remaja dan pemuda. Orang-orang tersebut dapat mengikuti kegiatan organisasi di sekolah atau kampus ataupun melalui komunitas. Kegiatan organisasi dapat dibagi menjadi tiga bagian, yaitu aktivitas, program dan organisasi yang dapat dilakukan setelah sekolah atau perkuliahan, ekstrakurikuler, musim panas atau liburan sekolah, tidak sekolah, dan di luar lingkungan sekolah.

Berdasarkan Peraturan Pemerintah Pendidikan dan Kebudayaan Nomor 81A Tahun 2013 tentang Implementasi Kurikulum fungsi kegiatan ekstrakurikuler antara lain: 1) Pengembangan, kegiatan ekstrakurikuler berfungsi untuk mendukung perkembangan personal peserta didik melalui perluasan minat, pengembangan potensi, dan pemberian kesempatan untuk pembentukan karakter dan pelatihan kepemimpinan; 2) Sosial, kegiatan ekstrakurikuler berfungsi untuk mendukung kemampuan dan rasa tanggung jawab sosial peserta didik. Kompetensi sosial dikembangkan dengan memberikan kesempatan kepada peserta didik untuk memperluas pengalaman sosial, praktek keterampilan sosial, dan internalisasi nilai moral dan nilai sosial; 3) Rekreatif, kegiatan ekstrakurikuler dilakukan dalam suasana rileks, mengembirakan, dan menyenangkan sehingga menunjang proses perkembangan peserta didik. Kegiatan ekstrakurikuler harus dapat menjadikan kehidupan atau atmosfer sekolah lebih menantang dan lebih menarik bagi peserta didik; 4) Persiapan karir, kegiatan ekstrakurikuler berfungsi untuk mengembangkan kesiapan karir peserta didik melalui pengembangan kapasitas.

Terdapat lima jenis kegiatan organisasi menurut Bonnie L. Barber (2005, dalam Mahoney, J. L., Larson, R. W., \& Eccles, J. S.): 1) Kegiatan prososial, yaitu tindakan sukarela yang ditujukan kepada orang lain untuk menunjang berlangsungnya kegiatan orang tersebut, tanpa mendapatkan keuntungan langsung; 2) Team sports, yaitu partisipan dari satu atau lebih sekolah yang bekerjasama dan membentuk satu tim; 3) Performing arts, yaitu partisipan yang berisi penampilan seni berupa band, drama, dan tarian; 4) School involvement, adanya keterlibatan dari kepala sekolah, pemilik klub, dan para ketua dari setiap organisasi; 5) Akademik klub, adanya kegiatan berupa debat, klub bahasa, klub matematika, klub catur, dan klub sains. 


\section{METODE PENELITIAN}

\section{Karakteristik Partisipan}

Responden dalam penelitian ini adalah mahasiswa dengan jumlah 640 responden. Adapun karakteristik responden dalam penelitian ini adalah berjenis kelamin laki-laki dan perempuan mengikuti kegiatan ekstrakurikuler dalam tiga bulan terakhir, minimal semester tiga, dan memiliki IPK. Sampel dipilih dengan menggunakan teknik non-probability sampling, yaitu accidental sampling.

\section{Alat Ukur}

Alat ukur keterlibatan dalam kegiatan ekstrakurikuler dalam penelitian ini dibuat sendiri oleh peneliti. Sebelum menuliskan kesebelas item di dalam kuesioner, peneliti melakukan review literature untuk melihat penelitian sebelumnya dan mengadakan wawancara kepada mahasiswa yang melakukan kegiatan ekstrakurikuler untuk mendapatkan gambaran terkait kegiatan yang dilakukan. Pilihan jawaban tersebar dalam lima skala poin Likert. Contoh item adalah saya terlibat dalam seluruh kegiatan ekstrakurikuler. Prestasi akademik diukur dengan menggunakan nilai IPK yang dilaporkan oleh partisipan.

\section{Teknik analisis data}

Penelitian ini menggunakan desain korelasional untuk mengetahui hubungan antara dua variabel yang diuji dengan menggunakan korelasi spearman. Analisis dalam penelitian ini menggunakan SPSS 22 for windows. Serta untuk menguji validitas menggunakan Software Lisrel versi 8.0.

\section{HASIL DAN PEMBAHASAN}

Peneliti mendapatkan 640 responden (laki-laki=41\%, dan perempuan=59\% mean usia=20 th) yang tersebar dalam lima kegiatan ekstrakurikuler, yaitu 63\% terlibat dalam 1 kegiatan, 25\% terlibat dalam 2 kegiatan, dan $12 \%$ teribat lebih dari 2 kegiatan.

Sebelum 11 item keterlibatan kegiatan eksrakurikuler digunakan, peneliti menguji apakah 11 item yang ada bersifat unidimensional, artinya benar hanya mengukur kegiatan organisasi. Dari hasil analisis CFA yang dilakukan dengan model satu faktor, ternyata model fit, dengan ChiSquare $=36.93, \mathrm{df}=25, \mathrm{P}$-value $=0,05859, \mathrm{RMSEA}=0,027$. Nilai Chi-Square menghasilkan P-value $>0,05$ (tidak signifikan), yang artinya model dengan satu faktor (unidimensional), di mana seluruh item mengukur satu faktor saja yaitu kegiatan organisasi. Lalu, peneliti melihat valid tidaknya item tersebut dengan dilakukan pengujian hipotesis nihil mengenai koefisien muatan faktor dari item. Pengujiannya dilakukan dengan melihat t-value untuk setiap koefisien muatan faktor. Jika t-value yang dihasilkan > 1,96 artinya item tersebut valid dan sebaliknya. Hasilnya adalah seluruh item dinyatakan valid.

Uji korelasi antara kegiatan ekstrakurikuler dan prestasi akademi menunjukan hasil bahwa terdapat hubungan antara kegiatan ekstrakurikuler dan prestasi akademik. Pada penelitian sebelumnya, (Darling dan kawan-kawan 2005, dalam Knifsend dan Graham 2012) menemukan bahwa kegiatan organisasi memiliki hubungan dengan prestasi akademik pada siswa sekolah menengah yang aktif dalam satu atau lebih banyak kegiatan serta memberikan dampak positif disekolah seperti keinginan yang kuat untuk mencapai keberhasilan pencapaian akademik, dibandingkan dengan siswa yang kurang aktif dalam kegiatan ekstrakurikuler. Kemudian, dalam penelitian (Dworkin dan kawan-kawan 2003, dalam Knifsend dan Graham 2012) menemukan bahwa kegiatan organisasi berhubungan dengan prestasi akademik, dimana mereka yang aktif dalam kegiatan ekstrakurikuler memiliki lebih banyak hal yang dapat 
dilakukan untuk membangun hubungan yang kuat dan suportif serta mendapatkan manfaat berupa pengalaman belajar dari kegiatan yang berbeda. Sejalan dengan dua penelitian lainnya, (Eccles 2006, dalam Knifsend dan Graham 2012) menemukan bahwa kegiatan organisasi berhubungan dengan prestasi akademik, yaitu ketika siswa aktif dalam beberapa kegiatan ekstrakurikuler menunjukan hasil bahwa mereka memperoleh nilai rata-rata yang lebih tinggi dan memiliki harapan yang lebih besar tentang pencapaian akademik dimasa sekolah dan setelah sekolah menengah.

Hal ini dapat diartikan keterlibatan dan keaktifan dalam kegiatan ekstrakurikuler mampu menciptakan terbangunnya hubungan yang kuat, suportif serta memiliki peran terhadap prestasi akademik. Dimana ketika mahasiswa memperoleh pengetahuan baru serta pengalaman belajar dari berbagai kegiatan yang diikutinya, tentu memperkaya pengetahuan yang sebelumnya ia miliki dan memberi kemudahan jalan untuk keberhasilan akademik. Kemudian, harapan terhadap pencapaian prestasi akademik setiap individu berbeda-beda, mahasiswa yang terlibat dalam kegiatan ekstrakurikuler memiliki harapan yang lebih besar disaat menempuh pendidikan dibandingkan dengan mahasiswa yang kurang terlibat dalam kegiatan ekstrakurikuler. Diakrenakan setiap individu memiliki cara berpikir yang berbeda dalam menanggapai suatu hal seperti saat sudah dalam dunia pekerjaan, diharapkan pengalaman berorganisasi yang diperolehnya dimasa perkuliahan menjadi salah satu keunggulan yang dimiliki yaitu dimana individu mampu menyesuaikan diri dalam organisasi tersebut.

\section{KESIMPULAN DAN SARAN}

Hasil dari penelitian ini menunjukkan bahwa terdapat hubungan dengan arah yang positif antara keterlibatan dalam kegiatan organisasi dan prestasi akademik. Dapat diartikan bahwa kegiatan ekstrakurikuler merupakan salah satu faktor yang mempengaruhi prestasi akademik seseoran, ditunjang oleh aspek-aspek yang ada didalamnya seperti keaktifan dalam beberapa kegiatan ekstrakurikuler, keinginan untuk membangun hubungan yang kuat dan suportif, serta harapan yang lebih besar dibandingkan dengan mahasiswa yang kurang terlibat dalam kegiatan ekstrakurikuler. Penelitian ini tidak terlepas dari kelemahan, mengingat dari temuan peneltian sebelumnya mengenai prestasi akademik ditinjau dari keterlibatan remaja dalam kegiatan ekstrakurikuler masih jarang yang meneliti, terbukti dari sulitnya peneliti menemukan dan mencari penelitian sebelumnya. Dapat di sarankan bahwa untuk penelitian selanjutnya di harapkan supaya penelitian mengenai prestasi akademik dan kegiatan ekstrakurikuler untuk dilanjutkan sehingga menghasilkan penelitian-penelitian yang lebih beragam. Kemudian, dapat disarankan untuk penelitian selanjutnya diharapkan karakteristik responden yang digunakan lebih bervariasi sehingga hasil dari penelitian tersebut dapat digeneralisasikan dan tidak hanya terhadap mahasiswa. 


\section{REFERENSI}

Chairiyanti, L., R. (2013). Hubungan antara Self-efficacy Akademik dan Konsep Diri Akademik dengan Prestasi Akademik. Humaniora, 4(2), 1125-1133. doi : 10.21512/humaniora.v4i2.3553

Cooper, H., Valentine, J. C., Nye, B., \& Lindsay, J. J. (1999). Relationships between five afterschool activities and academic achievement. Journal of Educational Psychology, 91(2), 369-378. doi : 10.1037/0022-0663.91.2.369

Departemen Pendidikan Nasional. (2011). Kamus Besar Bahasa Indonesia Pusat Bahasa Edisi Keempat. Jakarta: Gramedia Pustaka Utama.

Depdikbud. (2013). Peraturan Menteri Pendidikan Nasional Republik Indonesia (22). Di akses dari

http://www.slideshare.net/login?from_source=/mobile/wellyindrianykurniyawan/salinan -permendikbud-nomor-81-a-tahun-2013-tentang-implementasi-kurikulum-garuda28831731

Fakhriyah, F. (2014). Penerapan Based Learning dalam Upaya Mengembangkan Kemampuan Berpikir Kritis Mahasiswa. Jurnal Pendidikan IPA Indonesia, 3(1). doi : 10.15294/jpii.v3i1.2906

Fajrina, A. D., \& Rosiana, D. (2015). Hubungan Flow dengan Psychological Well-Being Mahasiswa Psikologi UNISBA yang Aktif organisasi. Di akses dari http://karyailmiah.unisba.ac.id/index.php/psikologi/article/view/1292/pdf

Inriyani, Y., Wahjoedi, W., \& Sudarmiatin, S. (2017). Peran Kegiatan Ekstrakurikuler untuk Meningkatkan Prestasi Belajar IPS. In Seminar Nasional Mahasiswa Kerjasama Direktorat Jenderal Guru dan Tenaga Kependidikan Kemendikbud 2016. Di akses dari http://pasca.um.ac.id/conferences/idex.php/gtk/aricle/view/246/233

Kurniawat, R., \& Leonardi, T. (2013). Hubungan Antara Metakognisi dengan Prestasi Akademik pada Mahasiswa Fakultas Psikologi Universitas Airlangga yang Aktif Berorganisasi di Organisasi Mahasiswa Tingkat Fakultas. Jurnal Psikologi Pendidikan dan Perkembangan, 2(1), 16-21. Diakses dari http://www.journal.unair.ac.id/filerPDF/jppp8592e834fc2full.pdf

Knifsend, C. A., \& Graham, S. (2012). Too much of a good thing? How breadth of extracurricular participation relates to school-related affect and academic outcomes during adolescence. Journal of Youth and Adolescence, 41(3), 379-389. doi : 10.1007/s10964-011-9737-4.

Kpolovie, P. J., Joe, A. I., \& Okoto, T. (2014). Academic achievement prediction: Role of interest in learning and attitude towards school. International Journal of Humanities, Social Sciences and Education (IJHSSE), 1(11), 73-100. Di akses dari https://pdfs.semanticscholar.org/b481/6f3f0c344184ec9f75dd7a6aef039a2bb80f.pdf

Mahoney, J. L., Larson, R. W., \& Eccles, J. S. (2005). Organized Activities as Contexts of Development: Extracurricular Activities, After-School, and Community Programs. New Jersey: Lawrence Erlbaum Associates. Diakses dari https://www.google.com/books?hl=id\&lr=\&id=0E54AgAAQBAJ\&oi=fnd\&pg=PP1\&d q=Mahoney,+J.+L.,+Larson,+R.+W.,+\%26+Eccles,+J.+S.+(2005).+Organized+Activiti es+as+Contexts+of+Development:+Extracurricular+Activities, + After-

School,+and+Community+Programs.+New+Jersey:+Lawrence+Erlbaum+Associates.\& ots=Lg10zs3m6i\&sig=uYBwgwNn4V2hsBLKXy8BFheFkMg

Mehus, O. M. (1932). Extracurricular activities and academic achievement. The Journal of Educational Sociology, 6(3), 143-149. doi : 10.2307/2961561.

Rivkin, S. G., Hanushek, E. A., \& Kain, J. F. (2005). Teachers, schools, and academic achievement. Econometrica, 73(2), 417-458. doi : 10.1111/j.1468-0262.2005.00584.x 
Sobur, A. (2006). Psikologi Umum. Bandung: Pustaka Sastra.

Untari, E. (2016). Korelasi Keaktifan Siswa Dalam Kegiatan Organisasi Sekolah dan Gaya Belajar Siswa terhadap Prestasi Belajar Matematika Siswa Kelas X Madrasah Aliyah Negeri Ngawi Tahun Ajaran 2014/2015. Media Prestasi, 15(2), 41-54. Di akses dari http://jurnal.stkipngawi.ac.id/index..php/mp/article/viewFile/103/pdf_41

Warsito, H. (2012). Hubungan Antara Self-efficacy dengan Penyesuaian Akademik dan Prestasi Akademik (Studi Pada Mahasiswa FIP Universitas Negeri Surabaya). Pedagogi: Jurnal Ilmu Pendidikan, 9(1), 29-47. Diakses dari http://ejournal.unp.ac.id/index.php/pedagogi/article/view/119/pdf. 